Modern Asian Studies 55, 5 (202I) pp. I68I-I7I7. (C) The Author(s), 202I. Published by

Cambridge University Press. This is an Open Access article, distributed under the terms of the Creative Commons Attribution licence (http://creativecommons.org/licenses/by/4.o/), which permits unrestricted re-use, distribution, and reproduction in any medium, provided the original work is properly cited.

doi:Io.IOI7/Soo26749X20000426 First published online or February 202I

\title{
Peasants, Colonialism, and Sovereignty: The Garo rebellions in eastern India*
}

\author{
SANGHAMITRA MISRA (D) \\ Department of History, University of Delhi \\ Email:smisra@history.du.ac.in
}

\begin{abstract}
This article studies two seismic decades in the history of the Garo community, marked out in colonial records as among the most violent and isolated people that British rule encountered in eastern and northeastern India. Through a densely knit historical narrative that hinges on an enquiry into the colonial reordering of the core elements of the regional political economy of eastern and northeastern India, it will train its focus on the figure of the rebellious Garo peasant and on the arresting display of Garo recalcitrance between I807 and I820. Reading a rich colonial archive closely and against the grain, the article will depart from extant historiography in its characterization of the colonial state in the early nineteenth century as well as of its relationship with 'tribes'/ 'peasants' in eastern and northeastern India. A critique of the idea of primitive violence and the production of the 'tribe' under conditions of colonial modernity will occupy the latter half of the article. Here it will argue that the numerous and apparently disparate acts of headhunting, raids, plunder, and burning by the Garos on the lowlands of Bengal and Assam were in fact an assembling of the first of a series of sustained peasant rebellions in this part of colonial India - a powerful manifestation of a community's historical consciousness of the loss of its sovereign self under British rule.
\end{abstract}

\section{Peasants, colonialism, and sovereignty: the Garo rebellions in eastern India}

This article studies two seismic decades in the history of the Garo community, ${ }^{1}$ marked out in colonial records as among the most violent

* Acknowledgements: I thank the Department of History, University of Delhi, for a Faculty Research Travel Grant for archival work, and the anonymous referees of Modern Asian Studies for their comments and suggestions. Rahul Govind has accompanied every word and argument of this article.

${ }^{1}$ In an earlier article on the Garos, I drew upon the works of Edmund Leach. I954. Political Systems of Highland Burma: A Study of Kachin Social Structure, London: Berg 
and isolated people that British rule encountered in eastern and northeastern India. Through a densely knit historical narrative that hinges itself on an enquiry into the colonial reordering of the core elements of the regional political economy of eastern and northeastern India, it will train its focus on the figure of the rebellious Garo peasant and on the arresting display of Garo recalcitrance between 1807 and I820. Reading a rich colonial archive closely and against the grain, the article will mark significant departures from extant historiography in its characterization of the colonial state in the early nineteenth century as well as of its relationship with 'tribes'/'peasants' in eastern and northeastern India. A critique of the idea of primitive violence and the production of the 'tribe' under conditions of colonial modernity will occupy the latter half of the article. Here it will argue that the numerous and apparently disparate acts of headhunting, raids, plunder, and burning by the Garos on the lowlands of Bengal and Assam were in fact an assembling of the first of a series of sustained peasant rebellions in this part of colonial India, a powerful manifestation of a community's historical consciousness of the loss of its sovereign self under British rule.

The first part of the article sifts through quotidian details of the prosperous trade in hill cotton in the early colonial period in the lowlands around the Garo Hills - taxes, measures, classes of traders, tables of rates - to discover the Garo community, zamindars, and European traders inhabiting a world of contested sovereignties in which they fought each other to control and regulate this trade. The continuation of this world into the early colonial period was decisively interrupted around I794, with the introduction of the Permanent Settlement of land revenue and the monopolization of the rights to the collection of sair $^{2}$ in cotton by the East India Company. The second

Publishers, and James Scott. 2009. The Art of Not Being Governed: An Anarchist History of Upland Southeast Asia, New Haven: Yale University Press, among others, to discuss the contingency and porosity of the nomenclature 'Garo' in pre- and early colonial historical sources. See Sanghamitra Misra. 2018. 'The sovereignty of political economy: The Garos in a pre-conquest and early conquest era', The Indian Economic and Social History Review, Vol. 55, No. 3, pp. 345-387.

2 "Sair means "movable" and the words combined are used to denote revenue not derived from land': F. D. Ascoli. 1917. Early Revenue History of Bengal and the Fifth Report, I8I2, London: Oxford University Press, p. 24. The rich historical scholarship on sair includes N. K. Sinha. 1956. The Economic History of Bengal. Vol. I: From Plassey to the Permanent Settlement, Calcutta: Published by the author; Ranajit Guha. I98I. A Rule of Property for Bengal: An Essay on the Idea of Permanent Settlement, Durham and London: Duke University Press; Kum Kum Chatterjee. 1996. Merchants, Politics and Society in Early 
part of the article tracks the impact of irreversible changes in the regional economic order, including on the relationship between the Garo community and lowland chieftains, and finds in them the historical context for the story of unfolding Garo violence in the early decades of the nineteenth century. Some apparent fissures discerned within the colonial archive will require an examination of the connections between the rationalization of violence and the new juridical regime introduced by the British state in the Garo Hills and in the valleys from about 18I6 onwards. The article concludes by capturing a fracture in time and narrative in the figure of David Scott, the official who 'pacified' the Garos. Scott's first deputation to the Garo Hills in I8I6 will provide a brief excursion into understanding the legitimization of executive power in the hilly parts of the empire which allowed despotic and brutal colonial governors to control the 'lawlessness' of colonial subjects.

\section{Traders, hill cotton, markets: the sovereignties of the early colonial period}

As the East India Company devised strategies of separation of the hilly parts of northeastern Bengal and western Assam from the valleys that encased them, the long histories of several polities exercising simultaneous political control and claims over hills and valleys begin to appear in its records. The Garos were one such polity and the manifestations of their control over and presence in the river valleys of Bengal and Assam, foothills, and hill passes in the early decades of the nineteenth century must form the very short but necessary prelude with which we will begin this article. Elsewhere I offer a more elaborate exposition of the irrefutable sovereign presence of the Garos in the pre-colonial regional political order of eastern India, as well as its firm location in the production of hill cotton. ${ }^{3}$ This article will study the Garo resistance to the shattering of this pre-colonial order by colonialism, with the violence of the peasant rebellions of the early decades of the nineteenth century setting the scene for the unfolding story of their becoming primitive hill 'tribes'.

Modern India. Bihar: $1733-1820$, Leiden: Brill; Sudipta Sen. 1998. The Empire of Free Trade: East India Company and the Making of the Colonial Marketplace, Philadelphia: University of Pennsylvania Press.

${ }^{3}$ Misra, 'The sovereignty of political economy', pp. 345-387. 
In the multiple and shifting system of alliances that was the essence of pre-colonial sovereignties in eastern India, the production and exchange of cotton from the Garo Hills held a central place throughout the Mughal period. Non-agricultural dues (sair) formed the key source of revenue for the majority of the zamindari estates (or choudhuries) of northeastern Bengal and western Assam, with a substantial part of the peishkash (tributary or honorary payment) paid to the Mughal faujdar (head of the police court) at Rangamatti being in elephants and aloe/ agar wood for the maintenance of the Dacca artillery park and petty garrisons. ${ }^{4}$ Most of these products were procured from the region of the Garo Hills, outside the political control of the Mughal state, where they were to be found in abundance. The inclusion of cotton as an article of significance within the peishkash cast Garo sovereignty in a determining role within the regional political order. Their military skill was now held up as a measure against which the prowess of the peishkash-paying zamindars was to be measured. ${ }^{5}$ In the notes of the earliest British officers, the Garos were 'the twins of the Marathas in the Deccan', wielding such sovereign powers as to fundamentally determine the spatial order of these parts of eastern India during the Mughal epoch. ${ }^{6}$

Mughal sources and contemporaneous evidence from the colonial archive suggest that the Garo polity, like many other contiguous polities, inscribed its political claims over a large swathe of the hills and plains. Though marked by a domination over land and by the introduction of agrarianization, ${ }^{7}$ such claims were characterized more by a ceaseless display of political power than by a uniform control over territory. ${ }^{8}$ Approaching the history of the Garos nearly two-and-a-half centuries after they first appear in British records, it might not be out

${ }_{2}$ February I8I9, Board's Collection, I8I8-I820 (henceforth BG), Asia Pacific and Africa Collections, British Library, London (henceforth APAC).

${ }^{5}$ For the conferring of various grades of military ranks on these chieftains of the plains, the Mughal state relied on an assessment of their military prowess vis-à-vis the Garos. See Letter of the Commissioner of Cooch Behar to the Board of Revenue, 30 April I794, $\mathrm{BC} / \mathrm{APAC}$.

${ }^{6}$ Misra, 'The sovereignty of political economy', p. 372.

${ }^{7}$ The Garos are repeatedly described as settled agriculturists in the colonial records, who cultivated a wide range of crops, including cotton. See 24 October I8I7, BC/ APAC; Report dated 20 August I8I6 from David Scott, Magistrate of Rungpore, to W. B. Bayley, Secretary to the Government, Judicial Department, Fort William, 24 October I8I7, BC/APAC.

${ }^{8}$ For a discussion of these political claims in the landscape of eighteenth-century eastern India and earlier, see Misra, 'The sovereignty of political economy'. 
of place to delineate some of the representative elements of the genre of historical work that studies polities conventionally defined as 'tribal' in the pre-colonial as well as the colonial period. ${ }^{9}$ While interrogating the classificatory regimes of the colonial state that draw upon evolutionist theories of European modernity to produce the category of the 'tribe' in colonies, many of these historians, such as Sumit Guha and Ajay Skaria, have also demonstrated the concrete historical processes under colonialism that led to the representation of the 'primitive' as outside of 'civilization'. These processes include the colonial state's attempts to 'extinguish wildness and to replace it with civilization: by halting raids, forcibly extinguishing mobility, imposing settled agriculture, and refashioning kingship to make it civilized'. ${ }^{10}$ Despite an acute awareness of the historical constitution of 'wildness', as well as of the flows of interdependence between hills and plains, there is a sense in which, in the final analysis, hills and plains remain as essentially impermeable categories in these works, and hill/forest polities are seen as discrete from the agrarian plains. ${ }^{11}$ This may well be a reflection of the specific conditions of the histories of the communities inhabiting these regions of western India or a consequence of an inadequate historical probing of their political economies. A recognition of the imperialism of

${ }^{9}$ The modernity of the concept of the 'tribe' and its constitution as a state/civilization has, of course, been the subject of serious anthropological and sociological work, a classic in the field being Morton Fried. 1975. The Notion of Tribe, Mento Park: Cummings Publishing Company. See also Andre Beteille. 1986. 'The concept of tribe with special reference to India', European Fournal of Sociology, Vol. 27, No. 22, pp. 297-318, where the author explores the continuously expanding category of the 'tribe' through the lens of livelihood, and returns to and confirms Fried's arguments, albeit with the caveat that the boundaries between 'tribes' in India are clearer that those Fried would allow for (p. 303).

${ }^{10}$ Ajay Skaria. 1999. Hybrid Histories: Forests, Frontiers and Wilderness in Western India, New Delhi: Oxford University, p. 6; Sumit Guha. 1999. Environment and Ethnicity in India, I200I99I, Cambridge: Cambridge University Press.

${ }^{11}$ The bind of the hill-plain dyad has, at times, generated ahistorical readings of communities, as in Jangkhomang Guite. 2015. Against State, Against History: Rewriting the Pasts of the Tribes of North-East India, Delhi: Oxford University Press. Such readings surface too in Prathama Bannerjee. 2006. The Politics of Time, Delhi: Oxford University Press, which tells the story of the primitivization of the Santhal community under colonial modernity. In the absence of a robust historical enquiry into their pre-colonial political economy, exactly what of Santhal life was disrupted by colonialism remains unexplained, and the community and its rebellions slip into becoming the ahistorical 'other' of the Bengal plains, ironically reproducing the very same image from the archive that the book seeks to interrogate. 
categories - 'tribes', 'civilization' - as well as of the historicity of the politics of wildness will not, however, suffice for writing the histories of communities such as the Garos, whose pre-colonial pasts were defined by a porosity that refuses to be sealed into compartments of either hill/ forest people or settled peasants of the plains. Oppositions of settlednomadic do not work for the Garos, for their history in the pre- and early colonial period is a negation of these very lines of difference and speaks instead of lives lived in the hills and plains but also in the passes and foothills in-between. Even as we draw upon the rich body of work on the 'tribe' in India, our enquiry will have to mark its lines of difference as it dwells upon a connected but distinct line of argumentation that sees 'tribes' as peasants. It will have to explore their embedding in, as well as production of, structures of land, market, and politics in the lowlands and in the highlands. It will find its affinities with historians who have returned to the archives to historicize the process of the construction of the 'tribe' in northeastern India, ${ }^{12}$ but also elsewhere in colonial India where the target of peasant insurgency - the oppressive trio of the sarkar-sahukar-zamindar - ${ }^{13}$ is easier to discern. For the colonial spatial order and its associated ideas of civilization-the

${ }^{12}$ Willem van Schendel's essay on the hill people of Chittagong, which dwells at length on the fluidity of ethnic identities and the impossibility of ascribing homogeneity to these communities, historicizes the category of the 'hill tribe' in the pre- and early colonial period and lists some of its many components: prisoners-of-war from Tippera taken to Arakan and then returning to the Chittagong hills, debt peons, migrants, and invaders: Willem van Schendel. 1992. "The invention of the "jummas": State formation and ethnicity in southeastern Bangladesh', Modern Asian Studies, Vol. 26, No. I, pp. 95-128. Boddhisatva Kar. 20I6. 'Nomadic capital and speculative tribes: A culture of contracts in the northeastern frontier of British India', The Indian Economic and Social History Review, Vol. 53, No. I, pp. $4{ }^{\mathrm{I}}-67$, locates the discourse of tribality in 'a connected history of the contractual and the customary' in northeastern India, revealing 'inconstant conjunctions between the styles of political control, the logics of capital accumulation and the discursive infrastructure of identity and difference'. More recently, Anandaroop Sen. 2018. 'Early years of East India Company rule in Chittagong: Violence, waste and settlement c. I760-179o', The Indian Economic and Social History Review, Vol. 55, No. 2, pp. I47-I8I, writes about the production of the uplands of Chittagong through a history of migration and settlement, kapas mahals as revenue geographies, and the figure of Jan Baksh Khan.

${ }^{13}$ The 'sarkar-sahukar-zamindar' (the government/regime-moneylender nexus) is of course Ranajit Guha's definitive formulation of the structure of oppression as well as the object of peasant resistance in colonial India: Ranajit Guha. 1983. Elementary Aspects of Peasant Insurgency, Delhi: Oxford University Press. For an analysis of Oraons as peasants and the location of their early twentieth-century rebellions within changes in the land structure and relationships under colonial rule, see Sangeeta Dasgupta. 2016. 'Mapping histories: 
designation of 'hill' polities as isolated zones and as various peripheries of valley state formations - to be truly challenged, the historicizing of the conjunction of ethnicity and habitat must be accompanied by more robust enquiries into the actual practices that constituted political orders which, more often than not, straddled not just hills and plains, but also the hill passes, rivers, and river ports. ${ }^{14}$ As the producer of a fine variety of hill cotton, a skilled agriculturist, and a trader who carried these bales of cotton down from the hill slopes to trade in the markets in the valleys and hill passes below, the Garo peasant straddled many worlds, refusing to be confined to any one of them. It is to some of these practices that we now turn in order to comprehend how this community of people came to be sequestered in the hills, defined and denounced, inspiring fear as well as a fierce will to control in colonial officials, their signs of violence providing the rationale for the British conquest of northeastern India.

Our interest here specifically lies in the zamindari estates of the three Istemarry Mehals (lands paying rent in perpetuity) of Karaibari, Kalumalupara, and Mechpara, with some necessary references to Sherpur and Shusung, the object of numerous Garo acts of violence in the first decade of the nineteenth century, with their estates the theatre of headhunting and murderous raids. After the acquisition of the Diwani in 1765 , the Company issued a series of Acts to regulate taxes and dues charged upon trade in transit. In the interest of maximizing their acquisition of revenue from customs, the Company abolished the practice of issuing dastaks (trading permits) in I77I, imposed restrictions on private trading by Company officials in 1773 , and abolished all private tolls across Bengal in I773 and government customs houses in I788. ${ }^{15}$ During the restructuring of the economy in the course of the Permanent Settlement, the right to collect sair duties was taken away from the zamindars, awarded to itself by the Company in I790, and (with certain exceptions) abolished in I79I. ${ }^{16}$

Many narratives of Tana pasts', The Indian Economic and Social History Review, Vol. 53, No. I, pp. I-3I.

${ }^{14}$ David Ludden. 2019. 'Cowry country: Where Zomia meets the sea', in Asia Inside Out. Vol. III, (eds) Eric Tagliacozza, Helen F. Siu and Peter Perdue, Harvard: Harvard University Press; David Ludden. 2003. 'The first boundary of Bangladesh on Sylhet's northern frontiers', Journal of the Asiatic Society of Bangladesh, Vol. 48, No. I, pp. I-54.

${ }^{15}$ Bengal Board of Revenue Files I786; Appt/r6 A: Abolition of Sair Duties, Fort William, 28 November i786, Assam Archives, Guwahati (henceforth AA).

${ }^{16}$ Ascoli, Early Revenue History of Bengal, p. 247. 
Listed as the chief landholders of northeastern Bengal in contemporary as well as later records, Karaibari, Mechpara, and Kalumalupara (and Habraghat), according to some colonial sources, were included in this rule of exception and exempted from the laws against sair collection that were in force in the rest of the British empire in India. ${ }^{17}$ While insufficient revenue from land, these estates' location in the midst of 'inaccessible hills and jungles', their separation from the nearest magistrate and the Collector by the Brahmaputra, and the expenses involved in policing a vast tract are offered as tentative explanations for this exemption, ${ }^{18}$ it is the primacy of the cotton trade with the Garo Hills that establishes itself as the sole basis for this exception in colonial records: 'These zamindaris are different from others in this: they pay their revenue from the sair and not from the mal [revenue]. ${ }^{, 19}$ In 1789 the payment in cotton had been commuted to money, but the payment of revenue was still from sair from the cotton trade. ${ }^{20}$

A set of letters from a quarter of a century later makes this governmental reason more intelligible:

The Board of Revenue in their late correspondence with the Government on the subject of the sair of these several estates on this frontier seems to be at a loss to determine under what grounds the abolition of the sair was not extended to them. It has been before shown that the revenue from the estates has, from the earliest times, been derived from the Garrow Cotton Trade, the circumstances probably had its weight with the Board. ${ }^{21}$

The 'earliest times' was a reference to the Mughal period, when these three Istemarry Mehals paid their peishkash 'from a traffic carried on with the Garrows in cotton and from duties laid on cotton'. ${ }^{22}$

${ }^{17}$ The exception made for the estates of northeastern Bengal was pegged on the sovereign presence of the Garos in the vicinity of these estates.

${ }^{18}$ Letter to the Board of Revenue from the Collector, Bengal Government Papers (henceforth BG), AA.

${ }^{19}$ Letter of the Commissioner of Cooch Behar to the Board of Revenue, 30 April I794, $\mathrm{BC} / \mathrm{APAC}$.

${ }^{20}$ The Translate of the Kabuliyat entered into for Karaibari Estate by the proprietor in the Bengali year iı95, BC/APAC.

${ }^{21}$ Extract, Judicial Letter to Bengal, which contains Sisson's report of I5 February I8I5, addressed to W. B. Bayley, Acting Secretary to the Government in the Judicial Department, Fort William, 2 February I8I9, BC/APAC.

${ }_{22}$ Additionally, the revenue was fixed at a low rate 'on condition that they should oppose the Garrow mountaineers, and prevent their invading Bengal, for these people made their invasions each year in the same manner that the Marhattas used to in the 
In the Company's positioning of resources, the forests, hills, and valleys inhabited by the Garos were identified as the most significant for governing the Bengal and Assam plains, and these pre-colonial conditions of assessment and payment, the archive argues, were allowed to persist without any significant increase in revenue or alteration in the management of the estates until I794. The late eighteenth-century/early nineteenth-century archive is saturated with references to the profitability of the trade in cotton, along with trade in other products from the Garo Hills such as agar wood, sago, and chunam (lime). The first British official to visit the Garo Hills did so in order to enquire into the volume of a superior quality of hill cotton which, he noted, was 'a source of immense profit for the zamindars'. ${ }^{23}$ About two decades after John Eliot, cotton (with seed and without seed) cultivated by the Garos in the Garo Hills and in the hilly areas of Karaibari and Mechpara estates was sufficient not just for consumption of the whole of Assam but additionally for export to Bengal. In Bengal, the quantity of Garo cotton equalled that produced in its most prosperous districts. ${ }^{24}$

A significant node in the political landscape of northeastern/eastern Bengal during this period was the figure of the zamindar/choudhury/ raja which necessarily combined within itself functions of an overtly military and political character. Colonial records and, following from them, recent historiography have portrayed these zamindaris and their relationship with the Garos as the quintessential example of an anarchical region where petty chiefs were in perpetual conflict. A more convincing historical interpretation might rest, however, on a recognition of the European understanding of limited sovereignty in which '(r)ather than signifying a quality that a state either possessed or failed to retain, sovereignty could be held by degrees, with full sovereignty reserved for the imperial power'. ${ }^{25}$ The zamindar of the Karaibari estate, in particular, appears to have achieved a measure of

south west part of India'. Letter of the Commissioner of Cooch Behar to the Board of Revenue, 30 April i794, BC/APAC.

${ }^{23}$ John Eliot, Report on Sherepore, I789, BC/APAC; also J. Eliot. I794. 'Observations on the inhabitants of the Garrow Hills, made during a public deputation in the years 1788 and i789', Asiatick Researches, 3, pp. 2I-45.

${ }^{24}$ The Buchanan Hamilton Manuscripts (henceforth BH), Appendix concerning the nations bordering in the Rongopur District, Mss Eur D 76, APAC. See Misra, 'The sovereignty of political economy', pp. 368-369 for more details on this prosperous trade in cotton from the Garo hills in the pre- and early colonial period.

${ }^{25}$ Lauren Benton. 2009. A Search for Sovereignty: Law and Geography in European Empires, I400-I9oo, Cambridge: Cambridge University Press, p. 245. 
supremacy that potentially challenged British imperial sovereignty at several points in the late eighteenth century. ${ }^{26}$

In the early years of British rule, or at least until i794, primarily on account of the rules of exception that allowed zamindars to pay their revenue with sair, the economic fortune of these chiefs continued to be tied to the wealth accrued from the regional trade in cotton. In the last instance, claims to political authority were dependent on the ability of each zamindar to mobilize individuals and groups in defence of the trade routes. The several recorded fights between zamindars over the control of trading passes ${ }^{27}$ but also between them, the powerful Garo traders, and the East India Company ${ }^{28}$ make this character of regional political power more than apparent. A much-cited case from 1793 involving two such Garo traders of significance, Rengta Booneah ${ }^{29}$ and Chila Booneah, reveals this intense contest over the monopoly of this very profitable trade in cotton as well as the determined resistance of zamindars to imminent changes in the structure of the pre-colonial economy by the colonial state. ${ }^{30}$

The spatial variations of sovereignty that the zamindars continued to command in the late eighteenth century were evident in their control over not just the lowlands but also over forts built strategically in hills,

${ }^{26}$ Letter of the Commissioner of Cooch Behar to the Board of Revenue, 30 April I794, BC/APAC, in Extract, Judicial Letter to Bengal, which contains Sisson's report, 2 February I8ı9, BC/APAC; John Eliot, Report on Sherepore, I789, in Extract, Judicial Letter to Bengal, 2 February I8ı9, BC/APAC. D. H. McDowall, Collector of Rungpore, to Cosby Burrows, Collector of Mymensingh, I3 July I787, Rungpore, Bengal District Records: Rangpur, Vol. 6, I786-1787, Letters Issued; Published at the Bengal Secretariat Record Room, Calcutta, 1928, India Office Records (henceforth IOR)/V/27/42/37.

27 'In I 775 the zamindar of Karaibari on the western outskirts of the Garo Hills invaded Garo territory and tried to establish himself as an independent ruler. He was successful until he invaded the hill area bordering on Sherpur and Shushung parganas in northern Mymensingh and put an end to the profitable cotton trade', BC/APAC.

28 The Commissioner of Cooch Behar noted in I794 that in I789, Hugh Baillie, a trader and Company official was 'attacked and defeated' by the zamindar of Mechpara, Ramchoudhury; 'the conduct of the Choudhury of Karaibari (was such that) he opposes the orders of the Government at all times'. Letter of the Commissioner of Cooch Behar to the Board of Revenue, 30 April i794, BC/APAC.

${ }^{29}$ The term 'Booneah' appears to have been used interchangeably for leaders in the community and traders of importance.

${ }^{30}$ Note from the Collector of Mymensingh, 7 March 1793, enclosing an Arzee from the Daroga of the Kapas Mahals near the hills of Sherpore and the jubabundy of Chila Booneah, IOR/F/4I5O5o. 
passes, and forests. These forts, which tended to be located at the intersection of land routes and connected to riverine ports, had decisive political and economic advantages, allowing zamindars to establish their monopoly over the products of the surrounding hills, including the most important local resource-cotton. ${ }^{31}$ That the Karaibari zamindar excelled in exercising control over the production of Garo cotton in the trading passes in the hills and owed his measure of sovereignty to this control is reiterated across colonial sources. ${ }^{32}$ The increase in the number of forts and guards in the passes controlled by him is noted with disapprobation by colonial officials who saw this as an attempt to establish a monopoly over this trade. ${ }^{33}$ Underlining the importance of this trade for the trading fortunes of the East India Company was the enquiry conducted by the Commissioner of Cooch Behar in August I790 at the behest of the Board of Revenue regarding 'the nature of the connection between Rungtah and the Karaibari zamindar'. ${ }^{44}$ The Commissioner's report confirmed all of the above: that Rahdarry duties from the trade in Garo cotton, paid by Garos and lowland merchants alike at the markets in the hill passes, formed the nucleus of the Karaibari zamindari economy (and of other estates such as Sherpore); that Rengta, the Garo 'chief' was the most important producer of this cotton and sold it all in a market near the Karaibari estate for at least the previous 40 years such that 'this conduct had received the sanction of custom'; and, finally, that the relationship between Rengta and the zamindar was 'amicable'. 35

Sovereignty in the pre-colonial period nested itself in alliances of kinship and marriage, and in individuals of influence; claims to territorial authority were therefore necessarily tenuous and transient. The

${ }^{31}$ In the late eighteenth century, the Karaibari zamindar had forts in Phulbari, Belbari, Singimari, Bagergaon, Garobadha, with regular burkandezes in each of these places, 25 April I8I7, Bengal Judicial Criminal (henceforth BJC)/APAC.

${ }^{32}$ On 7 March I793, the Collector of Mymensingh requested the Commissioner of Cooch Behar, C. A. Bruce, to direct the zamindar of Karaibari, Mohendranarain, 'to withdraw immediately guards of the Karaibari estate in the various roads and passes leading to the district' 'as the encouragement of the Garrows trade is an object which the Govt has much at heart, and have made considerable sacrifice of revenue to promote it', BC/APAC.

${ }^{33}$ John Eliot, Report on Sherepore, I789, BC/APAC.

${ }^{34}$ Ibid.

${ }^{35}$ Report of Douglas, Commissioner of Cooch Behar, in John Eliot, Report on Sherepore, I789, BC/APAC. 
'patchwork of identities'36 that characterized the lowlands over which the Garos laid claim in this period ensured that many of the zamindars/ tributary rajas belonged to this community. ${ }^{37}$ The overlapping character of sovereignty that these conditions generated continued for generations to come, and was on display in the ceremonial grandeur accorded to Agund, Rengta's son, by the Karaibari zamindar and in the influence that the former continued to command over the cotton trade and 'over local chiefs (Bhooneas and Gerees)'. ${ }^{38}$ Traces of this political order persisted into the late eighteenth century, despite the East India Company's interventions as Mohendranarain protected his uneven sovereignty, shared and contested with contiguous zamindaris and the Garos, with some military help from the latter. ${ }^{39}$ The above narrative of Garo agency counters the singular inability of modern historiography on the region to acknowledge the display of sovereignty in non-territorial forms.

The neat cataloguing of the colonial archive sometimes makes it easy for us to forget that the zamindars of northeastern Bengal shared their milieu with the nawab of Bengal, the French merchant Jean Baptiste Chevalier, and traders associated with the East India Company such as Henri Vannsitart. Cotton produced by the Garos and sold at the markets of Bengal was the primary concern in the debates over the monopolization of the trade in eastern India by traders associated with the East India Company and otherwise in the middle and late eighteenth century. In a series of letters to Vannsitart, Mir Qasim, the nawab of Bengal, accused private traders such as Chevalier and his gomastahs (trading agents) of depriving him of his rights to revenue amounting to $\mathrm{Rs} 40$,ooo in the form of duties on this trade. ${ }^{40}$ The cotton brought down by the

\footnotetext{
${ }^{36} \mathrm{Scott}$, The Art of $\mathcal{N}$ ot Being Governed, p. I72.

${ }^{37}$ Walter Hamilton. 1820. A Geographical, Statistical and Historical Description of Hindostan and the Adjacent Countries. Vol. I, London, p. 756 .

${ }^{38}$ Sisson quotes from John Eliot, Report on Sherepore, I789, BC/APAC. Similarly, on the Garos and the Karaibari zamindar, Buchanan Hamilton writes: 'They pay him no duties but on a certain day every year, he invites all the chiefs and free men of that nation. From 5 to 6 thousand usually attend, are feasted. Every one brings a present in cotton or other commodity which sells for about 4 rupees; so that, after defraying the expenses of the feast, the Raja has the profit of about I5,ooo rupees': BH/APAC.

${ }^{39}$ C. A. Bruce, Commissioner of Cooch Behar, to Walter Mac Guire, the Magistrate of Mymensingh, i8 October i794, BJC/APAC.

${ }^{40}$ Translation of a letter from the Nabob (of Bengal) to the Governor, in H. Vannsitart. 1986. A Narrative of the Transactions in Bengal, from the year I76o, to the year I764. Vol. 2, Calcutta: K. P. Bagchi.
} 
mountaineers, Vannsitart acknowledged to his colleagues, constituted the only form of revenue from the region of Rangamati in Bengal, a district bordering the Garo Hills. ${ }^{41}$ From John Eliot's account and correspondence, it is evident that until his visit of I788 the East India Company had been ignorant of the rich sources of cotton in the Garo Hills in the immediate vicinity of Bengal. It therefore required him to present his collection of taxes as a sovereign indivisible right, as a constitutive process of every imperial polity, Mughal or British. ${ }^{42}$ Eliot was also instructed to seek ways of establishing monopoly, through force and persuasion, over the considerable revenue accrued in this trade. ${ }^{43}$ Resistance to colonial interference therefore also manifested in the zamindars' reluctance to share details of revenue collection, both sair and mal, at the markets in territories they controlled. This dimension of the regional political order is concealed in later colonial correspondence, buried as it is in the language of severe moral condemnation of the zamindars.

However, a terrain where seasonal markets were scattered over a vast expanse of thickly forested hills and lowlands, unmarked by surveys and borders, would have allowed for a very uneven implementation of the official order to abolish the right to sair, if it happened at all. Eliot's exhaustive reports are peppered with frequent expressions of exasperation at the practices of the zamindars of Sherpur and Shusung, conveying the difficulty of monitoring the markets they controlled. Throughout the last decade of the eighteenth - and certainly into the early decades of the nineteenth - centuries, the zamindars of both these estates continued to collect the highly remunerative sair duties on the trade in cotton produced in the Garo Hills. In I789, the raja of Susung collected Rahdarry duties on Garo cotton in a long list of haats (seasonal markets) or kotes (seasonal markets) in the Garo Hills bordering the Sherpur pergunnah (subdivision of a tehsil [district]): Ramsingpore, Nithree, Aughar,

41 'As to trading by our gomastahs with the mountaineers, who came with cotton to Rangamettee if it has been a custom for that article to be farmed out by the country government, and it is from that only the revenue proceeds, I think we have no right to overrule that custom.' Copy of Mr Vannsitart's Letter to Mes. Johnstone, Hay and Bolts (William), dated Mongheer, I5 December i762: ibid.

${ }^{42}$ Eliot, 'Observations on the inhabitants of the Garrow Hills'.

43 'So much is the trade of the hills clogged with duties of heavy oppression that it is in a manner monopolized by a few, who are either ryots or residents in the zamindar's districts, and have it almost in their power to sell cotton on their own terms. To prove this, I need only state that by the time the cotton crosses the Brahmaputra, it rises in price from Ioo to I5o percent.' John Eliot, Report on Sherepore, I789, BC/APAC. 
Sheebpore, Suffore, Nulchupurrah, Punchgong, and Burradowarah. The raja of Sherpur had an equally long list of chowkis (toll/custom houses) at the Garo Hills passes in his part of the estate: Ghosegong, Foolbareeah, Bishnuparah, Bainjaun, Abrahamabad, Susung, Shokonah, and Baljury. Acutely aware that the rates in this very lucrative trade with the Garos were being manipulated and were unverifiable, Eliot nevertheless wrote about tables of 'general and monthly accounts' that included details of the volume of cotton sold at each of these passes and the duties collected by the zamindars. ${ }^{44}$

The duties collected at these haats were finely calibrated according to the rank of each trader, classified variously as merchants granted a sunnud (a deed/charter bestowed by a ruler), peddlers, shop merchants, confectioners, barterers, fishermen, salt merchants as well as sellers who had not sought permission earlier and therefore had to pay a fine to secure permission to sell their goods. ${ }^{45}$ For the right to sell his cotton in the mart, the Garos paid a duty - the 'Bucha Para' or the 'child load'-in the form of cotton to the moharir or mukhtar (clerks) of the haat. ${ }^{46}$ More than two decades after the official abolition of sair by Lord Cornwallis, Buchanan dreamed of a world with no monopoly or duties, except that of the Company's, and named Bijni and Howraghat, along with Karaibari, Mechpara, and Kalumalupara, as the pergunnahs where the zamindar continued to exercise their right to duties on the transit of goods: 'The Garos pays a share of the cotton (Phull) to the Raja for permission to trade in his market', while the other merchants paid transit duties. ${ }^{47}$

The willingness of these merchants to pay these duties commented upon in colonial records can be explained by the continued presence of the zamindar as the provider of infrastructure for trade in these markets, which they were responsible for maintaining. Available commentaries write about the regular farming out of the passes (frequently to the raja's old servants); the regulation of weights, measures, and rates of exchange; ${ }^{48}$ the security provided to the person and property of the

\footnotetext{
${ }^{44}$ From John Eliot, Commissioner of Sherpore, to G. C. Meyer, Acting Preparer of Reports to the Revenue Department, Revenue Board, Dacca, 6 August 1789, Bengal Revenue Consultations (henceforth BRC)/APAC.

${ }^{45}$ Ibid.; BH/APAC.

${ }^{46}$ Eliot, 'Observations on the inhabitants of the Garrow Hills', pp. $2 \mathrm{I}^{-}-45$.

${ }^{47} \mathrm{BH} / \mathrm{APAC}$.

${ }^{48}$ The regular staff at the markets included the daroga, the weighman, and the interpreter. John Eliot, Report on Sherepore, I789, BC/APAC.
} 
merchant; parity in the rates of cotton duties across the hill markets; the monetary currency in use, as well as the function of cotton as a measure and currency for all articles traded in the passes. ${ }^{49}$

These commentaries on the concrete practices and conventions of the cotton trade in these haats also make the grid of the regional political order intelligible. That Garos as a community and their primary product - hill cotton - were at the centre of this grid is more than apparent. The zamindar provided the conditions under which cotton trade could prosper. The Garos determined its order and orientation: the markets opened with the ritual feasting of prominent Garo traders by the lowland zamindars, ${ }^{50}$ and the terms of sale and exchange, including the sale of cotton on credit to lowland merchants, were decided by their leading traders, ${ }^{51}$ as was the price of cotton and the number of days of trading in these seasonal haats. ${ }^{52}$ The following description of the opening day of a haat at a Garo Hill pass is echoed across the eighteenth-century archive:

\footnotetext{
49 'A portion of the value of the cotton was paid for in Narayanee currency and at times in the Mughal currency prevalent in Bengal': BH/APAC. Eliot's reports on the duties collected by the Sherpore zamindar include tables of exchange between shop merchants and Garos. From John Eliot, Commissioner of Sherpore, to G. C. Meyer, Acting Preparer of Reports to the Revenue Department, Revenue Board, Dacca, 6 August I789, BRC/APAC.

${ }^{50}$ References to the feasting of Garos by zamindars and East India Company officials are plentiful in the Bengal Revenue Consultations. For several such references in just a single year-I789- see G. C. Meyer, to John Shore, President, and other members of the Board of Revenue, 3 August 1789, BRC/APAC.

51 'At the passes, the trade is from the beginning of Aghun to the end of Choite, and the arrival of the merchants at the passes is (brought to the notice of the Garrows) when Runtah Booneah, the head of the Hill Garrows in the neighbourhood, comes down and opens the trade; but no one dares to trade till all Runtah's cotton is disposed of; this is a mark of respect to Runtah and I am told Runtah might put what price he pleased in this his first sale, and the merchants would be obliged to take it at his terms, otherwise not one of the other Booneas and Garrows would sell any of their cotton': John Eliot, Report on Sherepore, I789, BC/APAC.

52 'There is no fixed haut after this ceremony, the Garrows come and go when they please but never remain out of their Hills beyond the second night, if their cotton is not disposed of within the that time, they go to the Daroga and tell him that they will not return if their quantum is not taken off their hands which seems to be no threat but really the case, therefore whenever this happens the Daroga gets some of the merchants to take it on trust in his presence and the Garrow receives his due. When he returns again the merchants are very just in the discharge of their credit, more from a fear of the Garrows than because of any unintentional uprightness in their dealings'. John Eliot, Report on Sherepore, I789, BC/APAC.
} 
Cote Foolbarree: The trade in this pass is from Caurtik to the middle and the end of Jote and is opened by an Interpreter, Weighman and merchant, going in to the Hills, and informing the Garrows that merchants are come to trade with them and that the zemindars will give them a feast after a certain number of Hauts. Whereupon a party of them comes down, opens the trade and settles a day for their feast and the articles of which it must consist, then the Garrows agree on that day to bring all their Booneahs, and a large quantity of cotton. ${ }^{53}$

Despite the careless use of the term 'tribute' in modern historiography, the duties paid by the Garos at the haats on the estates of the zamindars are nowhere classified as such in contemporary accounts of Henry Vannsitart, John Eliot, or Francis Buchanan. If tribute is understood as 'an essentially one way flow of resources (agricultural good or other commodities) from the members of politically subjugated and socially ranking strata of society to an "elite stratum", 54 then it is difficult to discern any of this in the relationship of the Garos with the zamindars. In fact, as the subsequent sections will argue, the origins, strategies, and flow of Garo resistance carried within them the signs and traces of these layered polities and political alliances.

\section{Understanding the signs of violence: the Garo peasant rebellions}

The structure of power and authority that sustained rural trade in this part of eastern India began to come under greater pressure when, from I794, the government started intervening directly in the collection and disposal of sair revenue. ${ }^{55}$ In the numerous markets along the Garo Hills and its passes, sair was now to be collected directly by the officials of the East India Company. A prehistory of establishing 'direct routes of conduit' with the Garos - that is, direct taxation without the mediation of the choudhuries/zamindars - lay behind the objectives of Eliot's visit nearly a decade earlier. Eliot's task had been to replace the zamindar's customary rights to transit and haat duties in cotton in the district of

\footnotetext{
${ }^{53}$ Ibid.

${ }^{54}$ Laura Lee Junker. 1999. Raiding, Trading, and Feasting: The Political Economy of Philippine Chiefdoms, Hawai'i: University of Hawai'i Press, p. 236.

${ }^{55}$ For an exposition of the strategic deployment of physiocracy and classical political-economy by the East India Company in their 'restoration' of the zamindar in such a manner as to deprive him of all juridical and political rights, as well as rights to tax commodities, see Rahul Govind. 2015. The Infinite Double. Persons: Things/Empire: Economy, Shimla: Indian Institute of Advanced Study, pp. 334-39o.
} 
Mymensingh (which had limited Company access to just a portion of the profits from the cotton trade) with direct access to Garo traders of importance, thereby erasing all 'ambivalences' that had come to be associated with sair in this part of Bengal. The estates immediately under review by Eliot were those of Sherpur and Susung on the southern borders of the Garo Hills which, unlike Karaibari, had formally lost their rights to the collection of sair in I788. In I793, when both estates were formally brought under the Permanent Settlement, the right to collect duties on the cotton brought down for sale in the markets were taken away from the zamindars and instead farmed out annually by the government to the highest private bidder. ${ }^{56}$ In the absence of sufficient and complete records from the zamindari estates, it is difficult to estimate their income from sair during the pre- and early colonial period. As an aggregate of all the markets in the land controlled by them, and with comparable figures from large zamindaris in Bihar, however, the income of both Sherpur and Susung from sair seems to have been considerable in the pre-colonial period. ${ }^{57}$ The prohibitions on the collection of sair, combined with the high rates of revenue under the Permanent Settlement, reduced the zamindars of these two estates to falling into debt and mortgaging their land within a few years of the establishment of the Settlement.

On the northern borders of the Garo Hills, the estates of Karaibari, Mechpara, and Kalumalupara, though not formally under the Permanent Settlement, had their rates of land revenue fixed in $1793 .{ }^{58}$ Subjected to high and fixed rates of revenue assessment and an unprecedented rigour in revenue collection, the effect of these new revenue laws on those zamindaris dependent on sair, in the form of seasonal duties acquired through trade with the Garos, was dramatic and instantaneous. Like many zamindars in Bengal, Bihar, and Orissa, the zamindar of Karaibari too went into arrears almost immediately after 1794, with its irregular kisht (instalment) payments stopping altogether in 1796 and its proprietor, Mohendranarain, in debt by $1798 .^{59}$

${ }^{56}$ I. Digby, Collector of Rangpur, to the Secretary to the Board of Revenue, 30 October 1812, BRC/APAC.

${ }^{57}$ Chatterjee, Merchants, Politics and Society, p. I33. Chatterjee estimates an income of Rs I,470 for Maharaja Kalyan Singh of Bihar.

${ }^{58}$ The land revenue of Karaibari was fixed at Rs 3,200, payable to the Company in five fixed kists.

${ }^{59}$ No. 17, 25 April I815, BJC/APAC. 
The assumption of the Company's right to collect sair was only one element in its expanding monopolization of all internal trade in eastern India; a further hollowing out of the institution of the haat would follow. In place of the many classes of traders and the conventions of free trade and exchange between Garos and non-Garos (described earlier in this article), there now stood the sole-monopoly might of the colonial state. With the duties previously paid to zamindars by traders now classified as 'undefined exactions' and 'various illegal monopolies of trade', the Company proceeded to determine the rates for the cotton brought down by the Garos from the hills. ${ }^{60}$ The Company's exclusive monopoly to the Garo cotton would have meant that the Garo cultivators lost their autonomy to engage with or desist from cotton cultivation at will. As officials pressed for the realization of arrears of revenue due from zamindars and trading began to be conducted under military authority, the solitary daroga found himself substituted with a more legitimate means of dominance: the Company troops posted in the haats. The presence of these troops, whose salaries were paid from duties on cotton paid by Garo cultivators, ensured that the mode of collection of taxes in the markets would have allowed for very little slippage.

Though yet formally 'unconquered' and therefore legally outside the new regime of political economy, ${ }^{61}$ the effects of the economic policies of the colonial state had thus begun to radiate upwards into the Garo Hills too by the late eighteenth and early decades of the nineteenth centuries. The state apparatus put in place for the collection of sair converged with the East India Company's assessment of the immense profitability of the cotton trade from the Garo Hills: ${ }^{62}$ in some sections of the archive, the conquest of the Garos was now stated to be eminently desirable, as 'a very great acquisition to the Government', their 'industry' manifest in the production of fine hill cotton and in its

${ }^{60}$ Extract, Bengal Judicial Consultations, 27 September i816, BC/APAC.

61 'The Garos of the greater part of the conquered tract were "much too independent to subject themselves to the Regulations of I793": Report dated 20 August I8I6 from David Scott, Magistrate of Rungpore, to W. B. Bayley, Secretary to the Government, Judicial Department, Fort William, Extract, Bengal Judicial Consultations, 27 September I8ı6, BC/APAC. In the entry on the Garos in Hamilton, A Geographical, Statistical and Historical Description of Hindostan and the Adjacent Countries, p. 756, he describes them as 'an independent people, even the British, as successors to the Moguls, having no claim on their lands, far less any zemindar under that government'.

${ }^{62}$ David Scott, Magistrate of Rangpur, to W. B. Bailey, Acting Secretary to the Government in the Judicial Department, 31 January i8ı6. 
potential increase. ${ }^{63}$ Officials agreed that Garo cultivators could be induced to increase the production of hill cotton by almost double the current amount: from 60,000 maunds to I00,000 maunds. There was also trade in precious agar wood, sago trees, and limestone. ${ }^{64}$

The earliest recorded massacres by Garo peasants in the Karaibari pergunnah in 1807 in the days leading up to the sale of Mohendranarain's estate acquire a new legibility and purpose when situated within this context of profound historical change. Over a period of one week in August 1807, 6o to 80 Garos attacked four villages - Goluknath, Falakhanah, Tikree, and Shital Kukree - killing dozens of people and burning the landlords' offices (kutcheris) and houses. ${ }^{65}$ Colonial officials noted that the last incident took place at a time when 'the police officers and party of sepoys were within a coss of the place'. ${ }^{66}$ These violent attacks were repeated across other estates in northeastern Bengal such as Sherpur and Susung. The state of revolt that appeared to prevail among the Garos during this period would only intensify in the next decade or so.

Denying them even the possibility of a common form, and hence any historicity or conscious political will, ${ }^{67}$ officials charged with the task of writing a contemporary narrative of these incidents of violence in the pergunnah of Karaibari classified them as 'crimes and offences perpetrated by that uncivilized tribe of people'. ${ }^{68}$ The Garo attacks on the villages of Karaibari pergunnah, however, were anything but a series of disparate, discrete encounters. Rather, they anticipated the rebellions that were to come as well as the common element that would bind them together. In $\mathrm{I} 80 \mathrm{0}$, the effects of the critical, irreversible changes introduced by the East India Company in the

${ }^{63}$ Thomas Sisson quotes from John Eliot, Report on Sherepore, I789, Extract, Judicial Letter to Bengal, which contains Sisson's report of I5 February 1815, addressed to W. B. Bayley, Acting Secretary to the Government in the Judicial Department, Fort William, 2 February I8ı, BC/APAG.

${ }^{64} \mathrm{BC} / \mathrm{APAC}$.

${ }^{65}$ M. Campbell, Magistrate, Rungpore, to the Governor General, 22 September I807, BJC/APAC; also Nos. 8-io, i4 November i8ı2, BRC/APAC.

${ }^{66} \mathrm{BC} / \mathrm{APAC}$.

67 'The object of this work is to try and depict this struggle not as a series of specific encounters but in its general form. The elements of this form derive from the very long history of the peasant's subalternity and his striving to end it': Guha, Elementary Aspects, p. II.

${ }^{68}$ G. Dowdeswell, Secretary of State in the Judicial Department, Fort William, to G. Hartwell, Acting Magistrate, Rungpore, 9 April I8II, BJC/APAC. 
political economy of the lowlands around the Garo Hills in the previous decades constituted this element, and this was made apparent in another series of rebellious attacks by the Garos on Karaibari on the estate of Sherpur in October of the same year. ${ }^{69}$ Colonial records noted that in both instances, they sought refuge in the fort of the Karaibari zamindar after the attack. ${ }^{70}$ This was, however, perhaps a mere dying flicker of a political authority in extremis; in the absence of regular surveys, undefined estate boundaries could also account for some lingering traces of Mohendranarain's political presence. ${ }^{71}$ It is possible too to interpret these moments as instances of solidarity between the Garo polity and the zamindars and choudhuries in the face of the dismantling of their earlier shared world of sovereignty and ethnicity. ${ }^{72}$

Mirroring these pre-colonial affinities and associations was the protracted conflict over Soondakhali, a portion of the Karaibari estate that consisted of hereditary rent-free portions (mahals) that Mohendranarain claimed were part of his son's Ultumgah estate gifted through a sunnud of the Mughal emperor. ${ }^{73}$ After the failure of a series of coercive methods to extract revenue, ${ }^{74}$ in I8og the East India Company had sold the estate of Karaibari at a public sale for Rs $93,500 .^{75}$ Invoking a shattered visage of his pre-colonial sovereignty, Mohendranarain now asserted that the purchaser of Karaibari, Ramnath Lahiri, could have no claims over the Ultumgah portion, which consisted of 185 villages and was also the pergunnah's most fertile and revenue-yielding portion-a

${ }^{69}$ In two consecutive attacks in May and October I807, Garos living in the surrounding hills killed 18 men and women, and wounded several villagers. 2 October I807, $\mathrm{BJC} / \mathrm{APAC}$.

${ }^{70}$ The Garos plundered Sherpur again in I8I ; Mohendranarain 'not often gave asylum to a large number of those who were concerned with the atrocities' that occurred in Sherpur. No. I7, 25 April I8I5, BJC/APAC.

${ }^{71}$ Though reduced to a financially precarious position, Mohendranarain continued to impress his political presence upon the British, occasionally strengthening forts within the Karaibari zamindari. Report dated 20 May 1806 from Mr Roberdeese, Acting Magistrate of Rungpore, BC/APAC.

${ }^{72}$ Misra, 'The sovereignty of political economy'.

${ }^{73} \mathrm{BC} / \mathrm{APAC}$.

${ }^{74}$ Company records mention the 'blow to the assumed independence of Mohendranarain' after the 'capture of his fortified residence by Captain Darrah in May I798', in consequence of which he immediately paid up his arrears: No. I7, 25 April I8I5, BJC/APAC.

${ }^{75}$ No. 35, 28 May i8II, BJC/APAC. 
claim that was contested by both the purchaser and the state. ${ }^{76}$ A protracted legal struggle over the possession of Soondakhali ensued for the next few years, but Mohendranarain's residence among, and his collaboration with, the Garos ('hill dependents') transformed this portion of land into a pièce de résistance of Garo peasant rebellion against the expanding logic of capital: Ramnath Lahiri, notes the file jottings, 'cannot be said to have had entire possessions of his purchase for a single hour'. ${ }^{77}$ The threat of violence from the surrounding Garo Hills was effectively conveyed: 'the purchaser would never be able to retain possession of even the lower hills and at a period when appearances might promise tranquillity, irruption might return in all its horrors and lay waste the whole country. The possession of the estate would subject the purchaser to continued alarms of conflagration and massacre' of Garo attacks. ${ }^{78}$

The Collector of Rangpur reported a complete inability on the part of the purchaser to collect the annual jumma (assessment or evaluation) ${ }^{79}$ and the government dropped its offers to buy the estate on account of its financial insolvency. In I813, Karaibari, one of the most prosperous of the Istemarry Mehals during the Mughal imperium, was in a desolate condition, its purchaser reduced to penury and imprisoned for 'non payment of one of the many pecuniary demands' and the colonial state forced into confessing that 'in a tract of such dimensions and so remotely situated, the difficulty and expense of supporting a police establishment are so great, that were it not opposed by political considerations it would be better to relinquish the sovereignty'.

These displays of solidarity apart, the long afterlife of sair in the zamindaris after its 'abolition', along with the colonial state's new and coercive regime of taxation, irreversibly altered the Garos' relationship with the zamindars of the plains in just a couple of decades, beginning

${ }^{76}$ To the Right Honourable Gilbert Lord Minto, Governor General in Council, Fort William, from R. Rocke, Revenue Board, 24 January I812, P/55/48, APAC.

77 Thomas Sisson's report in Extract, Judicial Letter to Bengal, 2 February I8I9, $\mathrm{BC} / \mathrm{APAC}$.

${ }^{78} \mathrm{BC} / \mathrm{APAC}$.

${ }^{79}$ To the Right Honourable Gilbert Lord Minto, Governor General in Council, Fort William, from R. Rocke, Revenue Board, 24 January I8I2, BRG/APAC.

${ }^{80}$ Hamilton, A Geographical, Statistical and Historical Description of Hindostan, pp. 762-763; BC/APAC. The disputes regarding Soondakhali and Karaibari remained unresolved and Karaibari remained an attached estate when David Scott assumed charge in I8I6. David Scott to W. B. Bailey, the Acting Secretary to the Government in the Judicial Department, Extract, Bengal Judicial Consultations, I6 February I8ı6, BJC/APAC. 
in the late eighteenth century. It is not clear from the records whether the zamindars of the estates bordering the Garo Hills continued to collect sair on behalf of the East India Company. Some records do suggest that, despite the persistent disinvesting of territory of the zamindar's long-held genealogical claims in the interests of the Company ${ }^{81}$ and promised punitive measures, the erstwhile Istemarry Mehals of Karaibari, Mechpara, and Kalumalupara (but also Shusung and Sherpur) continued to be dependent on the now 'illicit' collection of sair on Garo cotton to meet the Company's increasing demands for revenue as well as for the maintenance of the estate and personal expenses of the zamindar. In I8II and I812, the duties levied on all articles sold in the markets by the Garos, but particularly on cotton, classified as 'cotton sair', were still recognized as the principal resource of the Kalumalupara estate. ${ }^{82}$ Within the pergunnah of Karaibari, I27 Garo villages continued to pay khunta (a house tax), hence classified as sair, to the zamindars well into the first decade of the nineteenth century. ${ }^{83}$ Similarly, kurm collections (cotton in return for capital advances from zamindars), though abolished along with sair, continued to be claimed by the new purchaser of Karaibari from the Garos.

In parts of Mechpara and Karaibari, mutated forms of sair continued to add to the increasing tax burden for the Garo peasant. The flow of sair in duties in hill cotton during the Mughal imperium in these areas was maintained through a complex system of poonjee (capital) ${ }^{84}$ advances from the zamindars to the Garo peasants for which they were allowed an exemption from taxes (such as khunta) if they were cultivating lands within zamindari estates. ${ }^{85}$ The cotton acquired in return constituted the revenue paid by the zamindars to the Mughal faujdar. An early

${ }^{81}$ BC/APAC.

${ }^{82}$ G. Hartwell, Acting Magistrate, Rungpore, to G. Dowdeswell, Secretary of State in the Judicial Department, Fort William, 26 March i8ıı, BJC/APAC. G. Hartwell, Acting Magistrate, Rungpore, to G. Dowdeswell, Secretary of State in the Judicial Department, Fort William, 26 March I8II, BJC/APAC. This association of sair with zamindari control explains the colonial state's misrepresented allegations of 'fraud' and 'deceit'heavier metal scales, the demand for a larger quantity of cotton than the sum paid for - on the part of zamindars in their dealings with the Garos.

${ }^{83}$ McLeod, Magistrate of Rangpur to W. B. Bailey, the Acting Secretary to the Government in the Judicial Department, 9 September I817, BC/APAC.

${ }^{84}$ Cotton produced by the Garos, the production costs of which were paid in advance by the zamindars.

${ }^{85}$ David Scott, Magistrate of Rangpur, to W. B. Bayly, the Chief Secretary to the Government, enclosing the report on the Garo Hills, I5 August i8ı8, BJC/APAC. 
nineteenth-century petition from the zamindar of Mechpara claimed that this practice was still prevalent in their transactions with Garo and Rabha $^{86}$ peasants, ${ }^{87}$ despite the monetization of land revenue by the Company, ${ }^{88}$ and pleaded for its continuation. Since the colonial state classified the collection of poonjee cotton as sair duties, the petition and its enclosed pleas were summarily rejected. ${ }^{89}$

As with the collection of other forms of sair, the collection of poonjee cotton (and similar forms like kurm) therefore did not vanish under the new juridical regime; it persisted instead with a different meaning, in a reduced 'illicit form' that was definitive of the irregularities of colonial sovereignty itself. ${ }^{90}$ From the many recorded complaints of Garo peasants, it is certain that by making the collection of poonjee cotton illicit, the colonial state fundamentally transformed the economic relationship between Garo cotton producers and the zamindars as purchasers into a deeply exploitative one. Garo peasants categorized the poonjee advances forced upon them by zamindars for growing cotton as exploitative since they were paid only one-sixth of their value for the same, a rate determined by the colonial state. ${ }^{91}$ What in the pre-colonial period had been a system of duties connected to the trade in cotton was now converted under Company rule into a form of tribute to the state, its arbitrariness underlined in the monopolization of the rates paid for poonjee cotton by Company officials. ${ }^{92}$ The pre-colonial ratio of poonjee to cotton was upset

${ }^{86}$ In the period under study, the Rabhas were a community that inhabited spaces that overlapped with those of the Garos (including the Karaibari and Mechpara estates) and producers of good-quality hill cotton in early East India Company records. See, for example, Hugh Baillie, Collector of Rangamatty, in 'Extracts from the Reports of the Collectors and Commercial Agents made to the Bengal Board of Trade, I789-1790', in Reports and Documents connected to the Proceedings of the East India Company, APAC.

${ }^{87}$ Translation of a petition presented by Mohee Ram Choudhury, zemindar of pergunnah Mechpara, IOR/F/4/609/I505I.

${ }^{88}$ Thus the bucha para (a duty paid in cotton for the right to trade in the markets) was replaced by a tax paid in cash, at a rate of $\mathrm{I} 2$ annas for every maund of cotton brought by the Garo peasant.

${ }^{89}$ McLeod, Magistrate of Rangpur to W. B. Bailey, Acting Secretary to the Government in the Judicial Department, 9 September I817, BC/APAC.

${ }^{90}$ Benton, A Search for Sovereignty, p. 33.

${ }^{91}$ Translation of the statement of Ramrung Sirdar taken in the thana Dhubri in the Zillah of Rangpur on 7 April I8ı6. In the presence of six witnesses and David Scott, BC/APAC.

${ }^{92}$ For a study of the emergence of the science of political economy and the changing opportunistic employment of its categories, see Rahul Govind. 20II. 'Revenue, rent ... profit? Early British imperialism, political economy and the search for a differentia specifica 
and, with it, the ratio of power between the hills and the lowlands. It is this very quality of irregularity in its definition and applicability that rendered sair politically incendiary and marked out the haat as an analogical site of violent political confrontation for the first time in the modern history of the Garo Hills.

At the haat, the Garo cotton trader now paid heavier, fixed taxes on cotton. Apart from the market infrastructure, which was paid from the duties collected at the haat, duties from the cotton trade were also expected to cover the expenses of 'a native judicial establishment, a local corps and Garrow haat police'. ${ }^{93}$ In the first decades of the nineteenth century, the community also found itself bearing the additional burden of the karanjama (house tax), imposed to balance the Company's ledgers after the payment of compensation to the zamindars of Karaibari, Kalumalupara, and Mechpara after their rights to collect sair were abolished. ${ }^{94}$ This was in addition to the existent, but now formalized, khunta. ${ }^{95}$

Into the second decade of the nineteenth century, the conditions of Garo sovereignty were evidently in danger of being irreversibly altered. A pre-colonial regional political order that hinged on the production and trade in cotton, which enabled claims and counterclaims of sovereignties, was being replaced by the colonial state with a territoriality that had the sovereignty of the economy alone as its condition. The annihilation of the old order meant that the coercive force of the colonial state was now being used by the zamindars against the Garos as well. ${ }^{96}$ The Garo violence of this decade may well be comparable to that of the better

(inter se)', The Indian Economic and Social History Review, Vol. 48, No. 2, pp. I77-213. For a broader evaluation of the apparatus of imperialism as a critique of the complicity of the categories of classical political economy and political theory in their modern formulation, see Govind, The Infinite Double.

${ }^{93}$ Report dated 20 August I8I6 from David Scott, Magistrate of Rungpore, to W. B. Bayley, Secretary to the Government, Judicial Department, Fort William, Extract, Bengal Judicial Consultations, 27 September I8ı6, BC/APAC. Further, the machinery for the collection of sair in the post-I794 period would have included amlahs (clerks or ministerial officers), naibs (deputy/managers of a zamindar's estate), and moharirs, but also paiks (footmen) and burkandezes (mercenary soldiers and retainers), seeking to enhance their salaries with additional income in the form of collections from the Garos.

${ }^{94}$ Santo Barman. 1994. Zamindari System in Assam during British Rule: A Case Study of Goalpara District, Delhi: Spectrum Publishers, p. 63.

${ }^{95} \mathrm{IOR} / \mathrm{F} / 4 / 8 \mathrm{I} 9 / 2 \mathrm{I} 862$.

${ }^{96} \mathrm{BH} / \mathrm{APAC}$. 
recorded peasant rebellions of neighbouring Rangpur when it is understood as resistance to these changes, an attempt to reinstate their sovereign selves against both the zamindar and the state in its methods of mobilization and insurrection. ${ }^{97}$

In February i8I5, the Judicial Department of the East India Company received a thick file on the Garos, containing a report from Thomas Sisson, the joint magistrate of Rungpore district. Sisson's report, consisting of several pages, reflected on the conditions considered endemic to British rule in northeastern Bengal. It is the immediate context for the report, however, that interests us here:

The recent renewal of Garrow irruption, in all its former horrors of wanton conflagration and indiscriminate massacre, having rendered it necessary that I should without further delay lay before the Government, the information I have been able to collect, as to the probably origin of the barbarities. I submit the results of my enquiries on that subject. ${ }^{98}$

The results of Sisson's enquiry resemble an inventory of death and plunder perpetuated by the Garos, the signs of their terrifying violence strewn across several zamindari estates in northeastern Bengal and their practices of headhunting on spectacular display. While some of the 'most atrocious occurrences' were bracketed in the period between I807 and I8I4, several episodes of violence directed specifically at the estates of Karaibari, Mechpara, and Kalumalupara took place between I8I5 and 18 i6.

The unprecedented nature of this violence produces immense disquiet across the archive, encouraging several seemingly contesting, but actually converging, discourses on the Garos and their violence. The strand within nineteenth-century colonial discourse emptied the violence of the Garos of meaning and content, and reduced it to a vector of primitive unreason. 'The Garrows are, in common with most other savages, of a most vindictive disposition,' notes Sisson; ${ }^{99}$ others of his ilk

${ }^{97}$ I am persuaded by Kaviraj's specific characterization of the Rangpur Dhing as 'a peasant war' brought on by excessive taxation under the Company's regime: see Narahari Kaviraj. 1972. A Peasant Uprising in Bengal, I783, New Delhi: People's Publishing House, pp. 46-62. For a contrasting interpretation of the Dhing, see Jon Wilson. 2005. 'A thousand countries to go to': Peasants and rulers in eighteenth century Bengal', Past and Present, Vol. I89, No. I, p. 84, who reads it as a moment of 'negotiation within a flexible political order in which they were participants'.

${ }^{98} \mathrm{IOR} / \mathrm{F} / 4 / 533 / \mathrm{I} 2847$.

${ }^{99}$ Ibid. 
reiterated a similar tautological logic - the Garos are irrational, they raid, and hence they are primitive. Crude evolutionism proliferates: 'the barbarous and uncivilized nature of those tribes may frequently have led them to commit acts of wanton ferocity and rapine without their having been actuated by any motive of revenge for real or supposed industry'. ${ }^{100}$ The condition of primitiveness needed only to be enunciated in these sources - the Garo is indisputably primitivewithout qualifying exactly what this condition was.

Casting the Garos as the very image of violence, the archive then proceeds to bracket this violence outside of the surrounding plains: the moment of the raid is now inevitably the only moment of visibility of the Garos in the colonial archives - appearing suddenly in a moment of certain terror, the Garos raid, plunder, and carry away heads of plainsmen. Then just as suddenly, they disappear, scattering into the thickness of the surrounding hills. The passages which detail the rituals of headhunting among the Garos ${ }^{101}$ speak forcefully of the imperative of protecting the civilized plains from the contagion of violence emanating from the hills; ${ }^{102}$ they therefore resolutely fix the Garos as isolated savages in the hills. As the perpetuators of 'primitive violence', the Garos are now a constant threat to social order, to the regime of taxation and cultivation in the plains. Over the next few decades this manoeuvre, repeated across colonial notes, letters, and commentaries, helped to operate a framework for expanding colonial rule into the hills. The figure of the headhunter will serve as a necessary trope in this story of conquest and spatial reordering.

${ }^{100}$ Resolutions of the Vice President in Council (in response to Sisson's letter and report): Bengal Judicial Consultations, 25 April I8I5; W. B. Bayly, Acting Secretary to the Government, to Maxwell, Joint Magistrate, Rungpore, 25 April I8I5, BJC/APAC.

101 'It is observable too that they invariably carry away the Heads of the Persons who fall victims for their cruelty and the uses to which they are said to supply these Heads are extraordinary. Some say that they stick them upon the poles in their Front of their Houses and that every man is esteemed in proportion to the number of heads he is possessed of. Others say that the Head of a Bengallee is a necessary ingredient in the funeral pile of a Garrow and that the body cannot be burnt until this requisite article has been procured': Magistrate of Mymensingh, W. W. Massie, to G. Dowdeswell, Secretary to the Government in the Judicial Department, Fort William, 29 April I8II, BJC/APAC.

${ }^{102}$ See Ajay Skaria. 1998. 'Being jangli: The politics of wildness', Studies in History, Vol. I4, No. 2, pp. 193-215, for a rich and original analysis of the political economy of raids in the region of Khandesh in the late eighteenth and early nineteenth centuries. 
A variation within this strand achieved a curious simultaneity: it historicized the violence by ascribing it to the loss of Garo primitive sovereignty to the zamindars, but located this sovereign presence in an ahistorical, inaccessible past: 'It is the oppressive behaviour of the zamindars which forces the Garos to commit outrages on the inhabitants of the zamindaris rather than a natural inherent depravity of heart. ${ }^{, 103}$ Frozen in time and space, the Garo is reduced to a typology of 'a hill man' trapped in a permanent ahistorical binary with his antonym, the plains' zamindar; a perceived racial and cultural difference gave this binary the hold of primordial difference. Here Company rule is absolved of any historical role in the violence (itself understood as a fragment of a pre-colonial past) and presented as an extraneous intervention with altruistic motives of restoring peace and order into a region fraught with 'internecine feuds'. This approach surfaces in later colonial narratives as well as in more recent writings on the Garo Hills. ${ }^{104}$ Taken together, these strands anticipate the logic of the separation of the Garos from the zamindars, the hills from the plains, the savage from the civilized, the raison d'état for the colonial state's unfolding territorial sovereignty of the nineteenth century. By rationalizing 'a practice which places itself between a state presented as given and a state presented as having to be constructed', ${ }^{105}$ these strands necessarily obfuscate the imperial intent of conquering the Garos.

This intent is unmasked in a singular schism in the archive in the voice of the colonial official H. Fuller. The immediate context for Fuller's observations and letters to the judicial department in Calcutta was a series of murderous attacks by Garo peasants living in the hills around the Karaibari and Mechpara estates. ${ }^{106}$ His search for causality - 'the just cause'-led him to question the Garos' 'primitiveness' as the rationale for this collective violence and acknowledge instead the social and historical contingencies of their world in the early nineteenth century:

${ }^{103}$ Extract, Judicial Letter to Bengal, 2 February I8I9, BC/APAC.

${ }^{104}$ Jayanta Bhushan Bhattacharjee. 1978. The Garos and the English, New Delhi: Radiant Publishers; Nirode K. Barooah. 1970. David Scott in North-East India I803-I83I: A Study in British Paternalism, Delhi: Munshiram Manoharlal Publishers; Milton Sangma. I98I. History and Culture of the Garos, New Delhi: Regency Publications; Ellen Ball. 2007. They Ask if We Eat Frogs: Garo Ethnicity in Bangladesh, Singapore: ISEAS Publishing.

${ }^{105}$ Michel Foucault. 2008. The Birth of Biopolitics: Lectures at the Collège de France, 19781979, New York: Picador, p. 4 .

${ }^{106} \mathrm{H}$. Fuller, Magistrate, Rungpore, to George Dowdeswell, Secretary to the Government, Judicial Department, Fort William, 30 June I8ı3, BJC/APAC. 
From the indiscriminate manner in which they murder all who come within their reach without regard to sex or age, and from their never being known to plunder... (the) only measure for some peace is the purchase of pergunnah Karaibari from the present proprietor by the Government, and its restoration to the family of the former zamindar. This is the general opinion of the natives here who attribute all the outrages which have happened, to the sale of this estate in the year I809, and assure me that previous to this event, such excesses were never heard of. The Garrows respected and were attached to Mohendra Narain whom they called their Rajah and looked up to as their chief, and who is said to reside at present among them. ${ }^{107}$

Fuller's statement rejects a representation of Garo violence as transparent and ahistorical; its insistence on giving this violence some shape and purpose constitutes that rare admission in the colonial archive - that welcome tear in the pages of history - that helps the historian render intelligible the violence of these raids. ${ }^{108}$ Departing from the standard colonial official narrative which encases the rebellious violence of its subjects in a discernible pattern so as to effectively suppress it, Fuller acknowledged the relationship between the disruption of the regional political and economic order in this part of eastern India under East India Company rule and the violence emanating from the Garo Hills. ${ }^{109}$ More specifically, he recognized the stark manifestation of this disruption in the abject conditions of Karaibari and its sale in I8og. While officials noted 'some sort of outrage almost every year from the time of the sale of the (Karaibari) pergunnah', the incidents of violence begin to exhibit a greater frequency and regularity from around I8II onwards, gradually acquiring the character of a widespread political rebellion.

${ }^{107}$ Ibid.

${ }^{108}$ Fuller's view invites criticisms, but an attentive reading of the archive does allow us to rescue a few other voices which maintain the sale of the Karaibari estate as the explanation for Garo raids. This includes that of Hamilton, A Geographical, Statistical and Historical Description of Hindostan, p. 209; Report on the Garo Hills of 15 August I818, BC I825-I826/APAC; No. i5, i6 February i8ı6, BJC/APAC.

${ }^{109}$ Analogous processes were at work under Company rule in other topographically similar parts of India such as the Jungle Mahals. Sivaramakrishnan's work tells us that between the 1770 s and the 1820 s these regions were marked by 'protracted campaigns against jungle landlords; the construction of these people, their followers and the local peasantry as primitive peoples; attempts to consolidate and enhance land revenue; the chuar (rural militia) disturbances...': K. Sivaramakrishnan. i999. Modern Forests: Statemaking and Environmental Change in Colonial Eastern India, California: Stanford University Press, p. 29. 
The three consecutive attacks on the village of Saftoka in Karaibari perhaps constitute one of the earliest instances of Garo insurgency. They were led by the charismatic Garo, Manick Booneah, his name inevitably marked by the deep antagonism of the colonial state towards its rebellious subjects: 'barbaric', 'the leader of savage invaders', for example. ${ }^{110}$ A thousand rupee reward for his capture to ensure the 'tranquility of the pergunnah of Karaibari' was the only allusion to his able leadership in the rebellion. ${ }^{111} \mathrm{~A}$ series of attacks on the contiguous estate of Kalumalupara, this time under the leadership of the Garo rebel Kunker, confirmed the presence of ethnic solidarity, as did the spread of the violence across two of the largest Istemarry Mehals. Displaying organization and conscious leadership, thereby affirming the political character of their rebellion, ${ }^{112}$ these attacks also confirmed the Garo peasant's comprehension of their increasing loss of control over economic processes, including commonly held fishing rights to the Julkeer Mehal in the Kalumalupara estate. ${ }^{113}$

In its initial responses, it is this territoriality and the growing landscape of insurgency that the colonial state was determined to circumscribe. Denying the territorial scale of the rebellion, officials labelled these attacks 'local', to be responded to with punitive action, as with earlier incidents. ${ }^{114}$ The Garo peasant's landscape of resistance was evidently vast enough, however, for the regular police officers posted at Karaibari to ask for military troops from neighbouring Bengal and Assam to be sent to their aid, along with a large posse of burkandezes. ${ }^{115}$ As the insurgency spread, colonial officers demanded - and effected - a change in the territorial jurisdiction of Karaibari pergunnah from Mymensingh to Rungpore 'on account of some of the police stations of that district being better situated in point of contiguity for affording assistance in Karaibari, in case of any necessity, than any thanahs in Mymensingh'. ${ }^{116}$

${ }^{110}$ W. Massie, Magistrate, Mymensingh, to G. Dowdeswell, Secretary to the Government in the Judicial Department, Fort William, 28 February i8II, BJC/APAC.

${ }^{111}$ Ibid.

${ }^{112}$ Guha, Elementary Aspects, p. 6.

11326 March i8in, BJC/APAC.

114 'The best way to ensure good behaviour from the Garrows in future is by punishing them for their unwarrantable attacks': M. Campbell, Magistrate, Rungpore, to the Governor General, 22 September I807, BJC/APAC.

${ }^{115}$ Ibid.

${ }^{116}$ W. Rees, Officiating Judge, Dacca Circuit, to the Secretary to the Government in the Judicial Department, 25 October I8II, P/I30/42, APAC. 
All three Istemarry Mehals were the targets of well-planned Garo violence in the years of rebellion that followed. In 1815, several hundred Garos attacked the Rajbari or the residence of the late zamindar of Karaibari, Mohendranarain. The rebels 'burnt the house and the property contained in it and carried off the heads of seven persons amongst whom was the youngest son of Mohendranarain. They also wounded three persons severely and what is still more serious, they are said to have possessed themselves of about 150 stands of fire arms of various descriptions. ${ }^{117}$ Officials estimated the number of Garo rebels in the Karaibari attack at 'several hundred', a sharp increase from the hundred involved in Kunker's attack. A year later, the rebellion had taken on the character of an open and public event-'collective, destructive and total [in] its modalities' - ${ }^{118}$ and any assembly of Garos inspired fear among officials. ${ }^{19}$ On 9 Magh I8ı6, Garo peasants assembled in their thousands to attack the zamindar of Mechpara, Mohiram Choudhury, when he was returning to Chattabari haat from Mechpara after collecting revenue. So severe was the attack and so intense was his fear of the rebels that Mohiram decided to seek safety by living in the middle of a lake on a boat:

the Garos who were in ambuscade on both sides of the road allowed my Jemmedar and Burkandezes who had gone on before to pass but when I came they shouted and one of them stabbed me on the side with a javelin. I pulled it out and drew my sword to defend myself on which he jumped back. After seeing that they were going to murder me, I fled and arrived at Jellahpur. Behind me Ghunshyam and eight other persons were following, all of whom the Garrows have killed and beheaded. ${ }^{120}$

${ }^{117}$ Extract, Bengal Judicial Consultations, 7 February I8I5, BC/APAC.

${ }^{118}$ Guha, Elementary Aspects, p. Iog.

${ }^{119}$ On i4 February i815, a group comprising 3,00o to 6,00o Garos on their way to Singimari haat (which was located close to Karaibari estate) to sell cotton were fired upon by the Subahdar in Karaibari pergunnah. Two of them were killed and several wounded, while the rest fled, leaving their cotton bales behind. Enquiries into the incident concluded that 'the officer's conduct in firing upon them without any orders to that effect, appears to be highly culpable and under any circumstances, unjustifiable'. David Scott, Magistrate, Rangpur, to W. B. Bailey, Acting Secretary to the Govt. in the Judicial Department, Rangpur, I4 February I8I5, BJC/APAC.

120 'Extract from a letter from Mahiram Choudhuri, the zamindar of Mechpara to Gurumohan Chacki and Hariprasad Vakeel', 31 January ı8ı6, BJC/APAC. The zamindar's amlah was among those beheaded. 
In some of their most sustained and prolonged moments of rebellion in I8I5 and then in January of the following year, Garo rebels displayed their hostility by burning the residences of both the Mechpara and Karaibari zamindars, which they then proceeded to plunder: 'of everything including cash, grain, cotton, and the zemindari documents'. ${ }^{121}$ Thereafter the violence appears to have spread 'analogically', from a specific to a more general attack on the entire domain constituted by authorities - the plundering and burning of 'the granaries and Moffusil Cutcherries', the storehouses of merchants, and even an object of great economic value to themselves: cotton collected over five years. ${ }^{122}$ That the shift to a cash economy was total but forced was evident in the looting of cash during the rebellion. ${ }^{123}$

As the peasants fanned out into the lands of the Mechpara pergunnah, they burned villages (the daroga's report listed I2 such villages) and, according to the petition of the zamindar, killed more than 200 of his ryots, the rest fleeing to the neighbouring pergunnahs of Habraghat, Chapar, and Rangamati: 'these outrages have not been confined to any particular spot, but the whole pergunnah has been the scene of murders and the conflagration of villages, and no one can say who has fled and who has been murdered and how many villages have been burnt'. ${ }^{124}$ Evidence cited in colonial correspondence contradicts this story, however, emphasizing instead that the enmity of the Garos was not directed against the inhabitants of the low country villages, but against the person and property of the zamindars. ${ }^{125}$ When asked why they had 'murdered and committed such excesses' in the pergunnah of Mechpara, captured Garo rebels explained that their beheading of ryots and zamindar's men were acts of retributive justice, publicly performed, against the loss of their erstwhile economic sovereignty at the hands of the zamindar:

He (the Mechpara zamindar) would ruin us Garos ... the Rajah was always levying fines from us; we resolved to plunder the pergunnah and cut off the

121 Ibid.

122 Ibid.

${ }^{123}$ According to the daroga of the thana of Rangamati, about Rs 5,00o, collected as rent by the zamindar of Mechpara, was looted from him when he was attacked by the Garos. Translation of an Arzee from the Daroga of Thanah Rangamati, I3 February I8I6, BJC/APAC.

${ }^{124}$ Ibid.

${ }^{125}$ Letter to Digby from the Secretary to the Board of Revenue, I3 December i8i2, $\mathrm{BRC} / \mathrm{APAC}$. 
heads of the ryots seeing that if the Rajah retained the power he would not spare even our little children, but having collected the ryots would invade our country. ${ }^{126}$

The 'taking of heads' was also an act of restoring, albeit transiently, the pre-colonial order of political equilibrium. The disruption of the regional political order by the zamindar's presumed plans of invading Garo country with 'large guns' and men assembled at Tikri fort demanded a reciprocal action: 'I and Dang Sing and Daful and Ram Dang ... with our relations about 400 or 500 hundred garos with knives and spears and shields, laid in ambuscade to cut off the zamindar in Dhaharedurrah jungle when he should return from Tiekree. We accordingly attacked him and got 9 heads that day. ${ }^{, 127}$ At any rate, the position occupied by their erstwhile owners in the hierarchy of a new political economy of auctions and purchases would appear to have been a significant factor in determining the prices of heads. ${ }^{128}$ Contemporary accounts offer a graded range in the value of heads:

It is the mode of acquisition by battle, surprize, or ambuscade, that stamps in the opinion of the Garrows the value of a Bengalese scull, which is besides esteemed in proportion to the rank of its former possessor. In 1815 , the scull of Hindu factor, which during his life purchased the zemindary of Caloomaloopara, was valued at Iooo rupees; and that of Indra Talukdar, agent to the Currybarry zemindar, at 500 rupees, while the price of a common peasant's was only io or I2 rupees of deficient weight. ${ }^{129}$

The destruction of land and property was such that even two years after the attack, the ryots who had fled Mechpara refused to return and the ones who did, returned on condition of rent-free tenures, a situation that reduced the now mal-dependent zamindars to pay their revenue from borrowed credit. The enormity of the scale and destruction of the Garos rebellion is brought alive in the accounts of the daroga of the thana (police station) of Rangamati, of the colonial official in charge, and of the Mechpara zamindar, all of whom feared the inadequacy of the police and military establishment when faced with the methods of

${ }^{126}$ Translation of the statement of Ram Dang Sirdar Garo taken in the thana Dhubri in the Zillah of Rangpur on 7 April i816. In the presence of six witnesses and David Scott, $\mathrm{BC} / \mathrm{APAC}$.

${ }^{127}$ Ibid.

${ }^{128}$ This may explain the many references in colonial records to a Bengali head being a necessary component in the funeral pyre of a Garo, 29 April I8II, BJC/APAC.

${ }^{129}$ Hamilton, A Geographical, Statistical and Historical Description of Hindostan, p. 759. 
Garo warfare - cautious and hence perfectly secure against attack by regular troops. ${ }^{130}$ The impeccable fearlessness that the rebels exhibited, such that they could overpower the armed retainers of the zamindars, even when in close proximity to British troops, would have drawn substantially upon the solidarity in ethnic affinities found among Garos of contiguous regions. Anticipating later solidarities with neighbouring polities such as the Khasis, the rebellion in Mechpara saw the participation of Garos from across the lowlands and foothills girdling the Garo Hills: the Garos of Bara Hazaree, Karaibari, Singimari, Mechpara, Habraghat, Sherpoor, and Shusung came together in groups of between 2,000 and 4,000 for combined attacks with those of Mechpara. ${ }^{131}$

Contemporary sources unanimously attribute a causal connection between what they classified as disparate, limited incidents and the 'explosion of mass violence' in the pergunnahs of Karaibari and Kalumalupara and the appointment of David Scott as commissioner of Cooch Behar and as joint magistrate of Rangpur. For its manifest display of Garo violence, Karaibari was listed as Scott's additional charge ${ }^{132}$ after the rebellion broke out in I8I6, Mechpara too was placed under his jurisdiction. The legal and political authority possessed (and claimed) by Scott, his role as an imperial representative in determining the trajectory of British conquest of the Garo Hills and its people, his characterization of indigenous legal and political systems, and constant pushing of his jurisdiction beyond the line of political control are all deserving subjects of study which can only be gestured to here very briefly. In the immediate aftermath of the rebellions, as well as during the months when Garo rebels laid siege to the pergunnah of Mechpara, ${ }^{133}$ Scott's extensive tours reported on the conditions in the Istemarry Mehals. They allow us to discern, if only partially, the workings of the official mind: the system of repression of the peasant rebellion would be in the manner of "war with an independent state ... (with) the inconveniences that attend it; amongst which is to be reckoned the probability of the innocent suffering with the guilty'. ${ }^{134}$ The article will

\footnotetext{
130 2i February i816, BJC/APAC.

131 Translation of an Arzee from the Daroga of Thanah Rangamati, I3 February i8ı6, $\mathrm{BJC} / \mathrm{APAC}$.

${ }^{132}$ BC/APAC.

${ }^{133}$ Translation of an Arzee from the Daroga of Thanah Rangamati, I3 February i8ı6, BJC/APAC.

134 I6 January I8I5, BJC/APAC.
} 
conclude with an examination of some critical historical implications of these administrative perceptions.

\section{Conclusion}

In an unconcealed official confirmation of the comprehensive nature of the Garo rebellion across the Mechpara and Karaibari pergunnahs, David Scott had been charged 'not to effect a temporary suppression of the outrages committed by particular tribes of the Garos but the eventual establishment of a general system calculated to secure permanent tranquillity across the region'. ${ }^{135}$ For the Garo Hills and its surrounding zamindari estates in the early decades of the nineteenth century, this new system would make its appearance in the form of the Bhagalpur or the Cleveland Plan. Indicative of how certain geographical tropes acquire a centrality, and also a transferability in imperial pursuits in different periods of history, the Bhagalpur Plan for 'pacifying' the recalcitrant Garos reappears several times in the pages of the archive, ${ }^{136}$ and it constitutes the sum of Lord Hasting's suggestions to Scott in I8I6. ${ }^{137}$ As a typology of hills as political frontiers and their governance was reproduced across the British empire in India, the Garo Hills came to be included within 'a system for the due management of our whole line of frontier from Oudh to Arakan'. ${ }^{138}$ Embedded in the idea of circumscribing hills as zones of relative isolation, inhabited by backward races with archaic practices preserved in suspended time, this plan was originally effected in the I770s to sequester defiant communities such as the Mal Paharias, the Kols, and the Mundas in the hills of Bhagalpur, rupturing all previous history of contact with the plains below and destroying the autonomy of hill polities. ${ }^{139}$ Nearly five

${ }^{135}$ Copy of a letter N. B. Edmonstone and G. Dowdeswell, to the Court of Directors, 24 October I8I7, BC/APAC.

${ }^{136}$ The earliest references are possibly in Eliot's journal and from then on in correspondence relating to Garo violence in Extract, Judicial Letter to Bengal, which contains Sisson's report of 15 February I8I5 $_{1}$, addressed to W. B. Bayley, Acting Secretary to the Government in the Judicial Department, Fort William, 2 February I8I9, BC/APAC.

13725 April I8I5, BJC/APAC.

13824 October i817, BC/APAC.

${ }^{139}$ For the history of the Cleveland Plan as colonial ideology and practice, see Seema Alavi. 1995. The Sepoys and the Company: Tradition and Transition in Northern India, I770-I830, Delhi: Oxford University Press. Kaushik Ghosh. I999. 'A market for aboriginality: 
decades later it made an appearance in the vicinity of the Garo Hills as a transferable trope of imperial ideology, seeking to regulate and control the recalcitrant community of Garos.

In a 'settlement' laced with threats of violent subjugation and coercion in the form of fines and military aggression, any further resistance from the Garo cultivators ${ }^{140}$ would be met by the implementation of the Bhagalpur Plan for the subjugation of the intractable Garos of Karaibari and Mechpara, approved by David Scott. ${ }^{141}$ The clauses of the Tikri Duar 'settlement', drawn up to end the rebellion and signed by several Garo sirdars (leaders/commanders) on 5 March I817, ${ }^{142}$ mirrored the ideology of the Bhagalpur Plan, including its reconstitution of the hills around the estates as a zone of refractory wildness, separated in time and space from the plains of Assam and Bengal. ${ }^{143}$ It unambiguously classified the Garos as inhabitants of the hills or hill passes, and not the surrounding valleys and foothills. As hill tribes, their only natural habitat was the Garos Hills:

If any among of the Garrow tribes in general there should be an assembly or consultation with the view of invading the lowlands and committing violence on the Company's subjects, we engage to give immediate information of the same to the police officers and also of all invitations to make incursions of the above nature that may be made to the Garrows by the Company's subjects. ${ }^{144}$

Territorialization associated hills with remoteness and violence, their inhabitants mirroring the primitiveness of their habitat. Scott's rough sketch of the thana of Karaibari from I8I6 marks out its hills as inhabited by Garos who were 'supposed and indeed known to have been guilty of almost all the outrages committed in Karaibari and

Primitivism and race classification in the indentured labour market of colonial India', in Subaltern Studies. Vol. X: Writings on South Asian History and Society, (eds) Gautam Bhadra, Gyan Prakash and Susie Tharu, Delhi: Oxford University Press; Sivaramakrishnan, Modern Forests.

${ }^{140}$ To the 'unconditional subjugation' of the Garos advocated by his contemporaries, Scott added that resistance would be 'on pain of their having their property confiscated to Government': 5 March i817, BC/APAC.

${ }^{141}$ i6 February i8ı6, BJC/APAC.

${ }^{142}$ Agreement executed by the Garo Chiefs/Sirdars of Tikriduar on 5 March I8I 7 in the presence of David Scott, Joint Magistrate, Rungpore, 28 December I82 I, BJC/APAC.

${ }^{143}$ Scott's plans for the rebellious Garo peasants inhabiting the hills of Karaibari pergunnah, 5 March I8I7, BJC/APAC.

${ }^{144}$ Agreement executed by the Garo Chiefs/Sirdars of Tikriduar on 5 March 1817 in the presence of David Scott, Joint Magistrate, Rungpore, 28 December I82I, BJC/APAC. 
Kalumalupara'; the sketch concluded that 'the peculiar possession of the hills affords their possessors greater facility in committing depredations on the lowlanders'. ${ }^{145}$ This conclusion was drawn despite the fact that Garo peasants constituted the most significant proportion of the population in the estate of Karaibari, itself conjectured to have been under Garo control in the not very distant past.

That the Tikri Duar Agreement displayed Scott's legislative authority as well as his 'executive powers' as joint magistrate (in the form of the immediate terror of armed troops and severity of punishment for the continuing recalcitrant ${ }^{146}$ ) is acknowledged by the executor of the agreement, but expunged from all colonial records but one. ${ }^{147}$ The text of the agreement laid down immediate conditions for the rebellious Garos as well as a blueprint for the imminent conquest of their land by the British. Although the signatories to the agreement were individuals, the clauses were 'penally binding' on a total collective that included the Garo sirdars, their dependants, and the inhabitants of their villages. A very different form of social consciousness was being summoned into being under the Company's juridical regime, emptying earlier forms of meaning and content. The essence of this difference is distilled in the last clause of the agreement: 'For the due performance of these articles of agreement we also hereby become mutually responsible for one another and all engage to produce before the Magistrate's people at Tikree and one of our members who may fail to perform what is herein written.' The 'herein written' included the promise to be an active collaborator of the colonial state, to apprehend and deliver to the

${ }_{145}^{146}$ February i8ı6, BJC/APAC.

146 ،...[I] $\mathrm{t}$ is certain that they have been induced to accede to the terms required of them and to sign the agreement principally by the appearance of the troops in this quarter, and from dread of eventual damage to their possessions $\ldots$ in order to accelerate its [the settlement's] accomplishment I have in such cases to solicit the permission of his Lordship in Council eventually to burn the houses of such sirdars as may obstinately standout after the Proclamation has been duly published and explained'. David Scott, Joint Magistrate of Rungpore, to W. B. Bayly, Secretary to the Government, Fort William, 5 March I817, BJC/APAC.

${ }^{147}$ As an example, see the letter reporting on the appointment and activities of Scott on the Garo frontier from N. B. Edmonstone and G. Dowdeswell, to the Court of Directors, 24 October I8I7, IOR/F/4/I5050; Reports dated August I8I6, August I8I8, and I8I9 from David Scott, BC/APAC. Modern historiography reproduces this erasure of Scott's violence. See 'Frontier Troubles and Scott's Ascendancy', in Barooah, David Scott in North-East India; and 'Early Intervention', in Bhattacharjee, Garos and the English. 
officials at Tikri 'any Garrow belonging to this Doowar or pass (who) should be guilty of violence to the Company's subjects'. ${ }^{148}$

Fratricide was the new norm, and the oaths of solidarity and loyalty which had enabled the functioning of Garo assemblies now held distorted meanings, inverted to break exactly these forms of collectives. Emptied of their political meaning, violent practices from the pre-colonial period were characterized as moral failings or a mere threat to social order. ${ }^{149}$

The Garos resisted this marking out of space and its inhabitants through military force. The acts of rebellion that continued to mark the rest of the history of the nineteenth century reflected an uncertainty of structure and of identity - Garos as people who inhabited hills, plains, and the lands in-between, subsequently sequestered in the hills by the colonial statebut they also represent a permanent state of revolt in this political context, a refusal to be reduced to the classificatory term of 'hill men'. The task of the historian is to recognize this condition as endemic and as produced by British imperialism.

14828 December i821, BJC/APAC.

149 'We now swear upon a skull and upon earth and salt and upon our swords that besides the thirteen skulls brought away from our villages and now produced, we and our people have no others; we further on the part of ourselves and for all our brethren do abjure the practice of keeping or bringing and selling human heads, and we hereby consent that if even the fragment of a human skull shall thereafter if found in any of our villages, that village shall be liable to be burnt and the whole of the inhabitants fined and otherwise punished as the Magistrate may direct': ibid. 